\title{
Forged in Conflict: Francis Buckley, the First World War, and British Prehistory
}

\author{
Seren Griffiths ${ }^{1}$ - Nicholas J. Saunders ${ }^{2}$
}

Accepted: 29 September 2020/ Published online: 7 November 2020

(C) The Author(s) 2020

\begin{abstract}
Francis Buckley was extraordinary; an officer responsible for arming grenades, excavating trenches, surveying, sketch-mapping, and military intelligence, his actions were a roll-call of the First World War's bloodiest battles. The psychological toll was significant. War remade the man and created the archaeologist. Under fire, Buckley recorded prehistoric lithics on the Somme, a rich archaeological landscape, and a deadly battlefield. After the war, "tramping" the Yorkshire moors, Buckley applied military skills to excavate and record a key, but still understudied lithic collection. This paper explores Francis Buckley's war, its implications for the history of archaeological thought, and reasserts his under-acknowledged legacy.
\end{abstract}

Keywords Conflict Archaeology $\cdot$ History of Archaeology $\cdot$ Cambridge University $\cdot$ First World War · Mesolithic

\section{Introduction}

War creates as well as destroys - a quality it shares with archaeology (Saunders 2001:101). In the case of Francis Buckley (1881-1948, Fig. 1), the emotional and psychological costs of conflict were balanced, in part, by his contributions to archaeological practice as we recognize it today, prioritizing: meticulous fieldwork, recording, an appreciation of taphonomy, and early research into palaeoenvironmental data. His

Seren Griffiths

seren.griffiths@mmu.ac.uk

Nicholas J. Saunders

Nicholas.Saunders@bristol.ac.uk

1 Manchester Centre for Public History and Heritage, Manchester Metropolitan University, Rosamond St West, Manchester M15 6EB, UK

2 Department of Anthropology and Archaeology, University of Bristol, 43 Woodland Road, Bristol BS8 1UU, UK 
work included key observations about the British Mesolithic, prehistoric mobility, and raw material procurement. However, unlike more famous contemporaries also shaped by their wartime experiences such as Mortimer Wheeler and O. G. S. Crawford, Buckley is a largely underacknowledged figure in British prehistory.

This reassessment of Buckley sits within a renewed interest in archaeological investigations undertaken during the First World War - large, small, incidental, and including theaters of war beyond the Western Front. This wartime archaeology at the front needs to be understood as part of a wider archaeology of the front, itself integral to an interdisciplinary approach to the archaeology of modern conflict (Saunders 2012). Along the Western and Eastern fronts, there was a connection between the intensity of the fighting (especially artillery bombardment) and the discovery of archaeological remains from the European Paleolithic, Neolithic, Bronze Age, and Iron Age (Saunders 2010:4-7).

On the Salonika Front in northern Greece, the British and French allies excavated and competitively displayed an impressive range of classical remains (Shapland and Stefani 2017), while at Gallipoli in 1915, the Greek city of Elaious (itself associated with the Trojan War and Alexander the Great's conquest of Asia) was discovered by and excavated under Turkish fire (Mackie 2010: 216-219). Further south, along the Hejaz Railway, Turkish, British, and Arab combatants encountered the archaeological remains of Islamic, Byzantine, Roman/Nabatean, and more ancient sites (Saunders 2020). On the Channel Island of Jersey, a late Neolithic/early Bronze Age site was discovered and excavated as a result of land disturbance for the construction of a Prisoner of War Camp (Hawkes 1939:66n9., 179-180n9).

The recent 2014-18 centenary has added momentum, in understanding the archaeologies of the war, with the University of Queensland's First World War Antiquities project investigating artifacts brought back as souvenirs by Queensland service personnel (Donaldson and Asmussen 2020). University College London's Petrie Museum's Different Perspectives project documented wartime digging in Egypt to procure objects for American museums (Biddle n.d.). Cardiff University's Views of an Antique

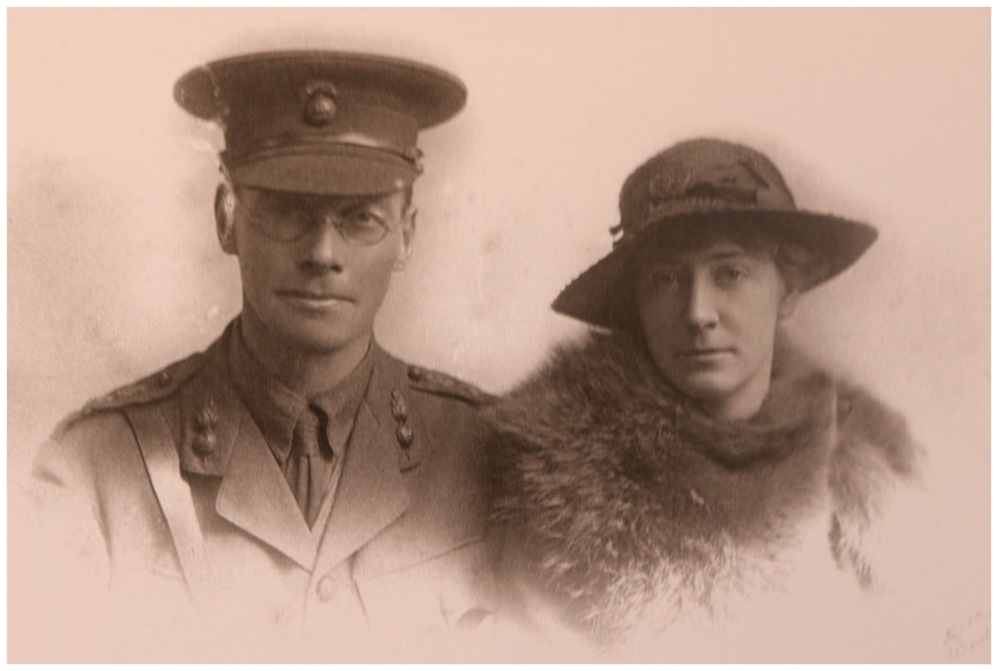

Fig. 1 Buckley aged 36 or 37 in 1918, with Bebba his new wife (@ Saddleworth Museum and Art Gallery) 
Land project is an online visual archive of Egypt and Palestine during the First World War (VAL n.d.), and The Visual and Material Culture of Military Encounters with Egypt, 1914 - 1918 / 1939 - 1945 is an insightful Facebook page (ECA n.d.).

In understanding the war's role in the history of archaeological thought, two classes of archaeologists can be distinguished. First are established archaeologists who took their nineteenth-century intellectual frameworks and practice into the trenches figures such as the eminent French researchers Joseph Dechélette and Maurice Bourlon, both killed during the conflict. In this class also was the British archaeologist Mortimer Wheeler, who studied Classics at University College London before the war, followed by a studentship in archaeology funded by the Society of the Antiquaries to study Roman pottery in the Rhineland (Piggott 1977: 624). In 1913, Wheeler was working for the Royal Commission on Historical Monuments (R. Clark 1960). Wheeler's war included being mentioned in Dispatches for capturing German artillery at the Butte de Warlencourt, the Somme burial mound of a Gallic chieftain in Roman times, which the Germans had entrenched (Wheeler 1955: 48-50, Fig. 2). Francis Buckley was also at the Butte de Warlencourt, but two years earlier, when he took part in the attack on Hook Sap in 1916 (see below).

A second class of archaeologists is more unusual, as they discovered archaeology through their war experiences. Here we can include British archaeologists O.G.S. Crawford, and Francis Buckley. While Crawford became part of the academic establishment, Buckley was a different type of archaeologist who was formed on the Western Front of the First World War. To paraphrase Wheeler (1955: 37), in an era in which war became commonplace, Francis Buckley was uncommon. Buckley did not bring a pre-existing specialism and he did not subsequently become an established academic archaeologist. Instead, through his exposure to the technologies, methods, and experiences of the first global industrialized modern war, Francis Buckley developed his own standard-setting archaeological fieldwork, as a unique response to

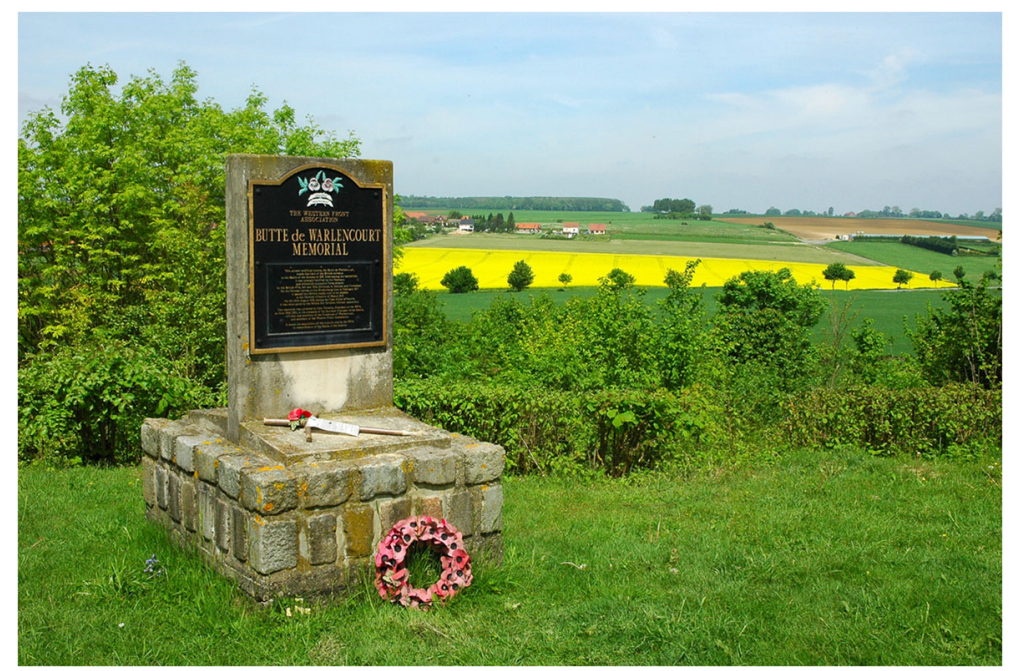

Fig. 2 The war memorial at the Butte de Warlencourt, a prehistoric burial mound near Warlencourt, which was the site of some of the heaviest fighting in the 1916 Battle of the Somme. Francis Buckley and Mortimer Wheeler were here at different times (@ N.J.Saunders) 
military fieldcraft. In one sense, this was highly unusual, but in another it was typical of the way the intensity of the war affected men who "were physically and symbolically folded into landscape and emerged remade" (Saunders 2004:9) — "formed as subjects by the technology they use[d]" (Gosden 1999:161).

Francis Buckley was born in 1881, and followed his family profession, becoming a barrister in 1905. In 1914, a year after their father died, his elder brother Richard probably committed suicide - a death seldom spoken of and referred to as an "accident with a gun" (G. Buckley). Richard's death left Francis as inheritor of the family's $£ 91,571$ estate, a millionaire in today's money.

When the First World War began, Francis Buckley was a member of the Lincoln's Inn Officer Training Corps. His poor eyesight initially prevented his enlistment, an irony given his subsequent experience. Appalled by the German sinking of the Lusitania in May 1915, Buckley enlisted as a $2^{\text {nd }}$ Lieutenant in the $3^{\text {rd }}$ line Battalion of the 7th Northumberland Fusiliers (Territorials), as the "rush of officer recruits had died down...they were not so particular about eyesight" (Buckley 1920:2). Buckley joined a regiment nonlocal to his native Yorkshire, so that he might not display "ignorance of things military before a group of neighbours [sic] and possibly relations" (Buckley 1920:5).

After initial training as a "grenadier" or bombing officer, responsible for fusing and coordinating the use of hand grenades, Buckley travelled to France in January 1916. He saw action in the major Western Front engagements - Ypres, the Somme (including Mametz Wood), Arras, and Passchendaele. He was mentioned in The London Gazette of May 22, 1917, for a Dispatch by General Douglas Haig, Commander-in-Chief of the British Expeditionary Force, dated April 9, 1917. His account in his war memoir, Q6A and Other Places (Buckley 1920), means the award likely relates to the first day of action in the Second Battle of Arras (August 26 -September 3, 1917), when he was gassed and slightly injured, though the memoir does not mention the award. Buckley was demobbed or "disembodied" as he called it on February 13, 1918.

\section{On the Western Front/Conflict Makes Archaeology}

Buckley's Division arrived on the Somme on August 17, 1916. Here, he was first exposed to the horrors of modern industrialized war. Of an early action he records:

I have no pen to describe the conditions [between October 25 and November 15, 1916]...faced by the brave men, who, after labouring [sic] unceasingly in the slimy horrors and rain for three weeks without rest or relief, stormed and took Hook Sap, only to be cut off and killed to the last man by successive counterattacks (Buckley 1920:92).

As Commander of C Company, and Battalion grenadier officer, Buckley trained men in the use of grenades, each of which he fused himself. This was dangerous work. By the time his division left the area, only 11 of his Division's 80 original bombing officers survived, and of the company trained by Buckley, only two. In December 1916, he was appointed an Observer in the $149^{\text {th }}$ Infantry Brigade (Buckley 1920:102-103). 
In preparation for this role, Buckley was instructed in drawing panoramic sketchmaps locating enemy positions for British artillery bombardment, and recording enemy movements in field notebooks (Gough 2009). From June to October 1917, he served with Intelligence personnel in the line, and on salvage duties out of it. He wrote the Brigade Intelligence Report, supervised Observers, marked "Intelligence maps with all features of interest" (Buckley 1920:144) catalogued "the aeroplane [sic] photographs which came in large numbers every few days and sent "the Machine-Gun Officer...the targets for indirect machine-gun fire at nights" (Buckley 1920:144).

Buckley's salvage work out of the lines gave him an appreciation of "souveneering," a deeply embedded and widespread wartime phenomenon with financial, emotional, and identity-building aspects (Cornish 2009; Saunders 2003a: 127-141). In some cases, this included the collection of ancient artifacts, such as the German solider excavated in 2003 from the frontline at Serre with a Bronze Age scraper his knapsack (Brown 2009: 273-275). So lucrative was it that it supported a group of Allied deserters who sold ancient and modern artifacts at army canteens (Buckley 1920: 151).

Buckley discovered archaeology in November 1917, when he and his commanding officer, Lieutenant-General G.R.B. Spain, identified "several early flint implements and arrow-heads about Serques." Spain was a Fellow of the Society of Antiquaries, and after the War became a museum curator (Cowen 1962). He told Buckley "a lot about the early Stone Age, which interested me greatly and set me looking for these interesting relics wherever we happened to be" (Buckley 1920: 161-162).

Buckley's war memoir, like many others, contains many examples of sensorial trauma, which occurred immediately he entered the trenches trauma-for example digging a machine-gun emplacement and having to lime the bodies of German soldiers found in the process. In 1916, after the Hook Sap attack on the Butte de Warlencourt, his Commanding Officer arranged leave for him on the grounds that Buckley looked "rather war worn." Buckley arrived in Britain to spend the entire time in bed "utterly worn out, not only with exhaustion, but with the depression naturally caused by losing so many friends" (Buckley 1920: 98). By late 1917, he was at the Battle of Passchendaele in Belgium, which "reeked like a slaughter house" (Buckley 1920:168) from scores of unburied men and horses. His depression was accompanied by an increasing disregard for his own welfare, which included "walking the top" of freshly turned trenches - a habit perilous for personal safety, but an excellent opportunity to observe the archaeology (Smith 2012: 8).

This potentially lethal behavior was combined with a developing exactitude in observation and excavation for military and archaeological purposes. In February 1918, he served as a Pioneer with the $42^{\text {nd }}$ Lancashire Division, leading hand-picked men digging reserve trenches, ammunition dumps, and machine gun emplacements (Buckley 1920: 173). In March 1918, as the British Third Army prepared for an expected German summer offensive. Buckley and his men's fieldwork was to observe and report enemy movements under constant shellfire. The rigors of this led Buckley to describe himself as looking "a very tramp, boots worn to pieces, clothes hanging with mud, and thick with mud up to the eyes" (Buckley 1920:200). At one point, Buckley and his men nearly ended up in German lines.

From May to June, the $7^{\text {th }}$ Northumberland Fusiliers were billeted at Coigneux, southwest of Arras, $6 \mathrm{mi} \mathrm{(ca.} 9.5 \mathrm{~km}$ ) behind the British front-line. Due to the shelling, they were ordered to "dig in," creating "a small trench...for each [Officer] inside the 
tent... It was rather like a shallow grave, but it gave you a feeling of security when bits were flying about" (Buckley 1920: 205). The privations of fieldwork, camaraderie of hand-picked men, and interlinking of military and archaeological practices, seem to have taken on a central place in Buckley's post-war methods (see below).

From May 1918, Buckley's Observers moved to a new strategic position, from which they made a critical contribution to the war. One Observation Post (O.P.) they established on "high ground between Coigneux and Bus, well back from the shelled and bombed area." (Buckley 1920: 208) was nicknamed "Eve" O.P. The forward "Adam" O.P. was "about four miles away in a small trench on the ridge north of Auchonvillers near some apple trees, which perhaps suggested the name" (Buckley 1920:208). This was a period of concentrated activity, and Buckley and his men were again under intense fire, working long hours with limited rest. From Adam O.P., they were some $4000 \mathrm{yd}$ (ca. $3.6 \mathrm{~km}$ ) from the German front line. From here, Buckley and his men could see "Q6A," the location of a German position from which Buckley's memoir takes its name, on an area of high ground "where anyone approaching...had to cross a ridge and so come under our observation" (Buckley 1920:213).

Q6A seems to have had a special, perhaps sinister resonance for Buckley. In his memoir he states that the book title "is taken from a spot where a small party of the 7th N.F. did something...to avenge their fallen comrades." This may allude to Buckley's Observers calling in heavy artillery to target Q6A on August 9, 1918, as retribution for the huge losses the battalion suffered at the Battle of the Somme. From their location at Adam O.P., Buckley and his small group of hand-picked men had been watching the German lines. On the August 6,1918 alone, they observed 1126 infantry soldiers and 55 transport vehicles from this position. Buckley and his men then watched as the Germans were blown up, as a result of the co-ordinates he had sent to the British guns. The impact of using modern technology-telescopic sights and telescopes - to watch as people were killed on his orders may have had a significant impact on Francis Buckley's consciousness (as we discuss below).

From 1916 to 1918, over the course of his war, Buckley's archaeological practice became increasingly closely intertwined with the practice of conflict, as for example this flint artifact recovered from a shell-hole demonstrates (Fig. 3). As with so many soldiers, the material culture he recovered became imbued with personal and sometimes life-changing experiences of war (Saunders 2003b:14-17). In 1918, while at Adam O.P., Buckley notes that he gave one lithic artifact to Private J. King, a hand-picked man. In the midst of this mayhem, archaeology was at the forefront of Buckley's mind.

During his times in the lines, Buckley's skills as a military Observer and archaeologist were developed in tandem as interlinked aspects of his fieldwork; the skills he was trained in to direct artillery fire, he adopted for archaeological recording (Fig. 4).

I asked the observers to make telescopic sketches, on every compass bearing, of what they could see. And then from these sketches and with my own maps and protractor I was able to tell them what they were looking at on the map, and to prepare a panoramic sketch for their use at Adam O.P. (Buckley 1920: 214).

Between June and July 1918, Buckley supervised digging of the "Red Line" trenches at Coigneux, and on inspecting them discovered an assemblage of Paleolithic lithics, 


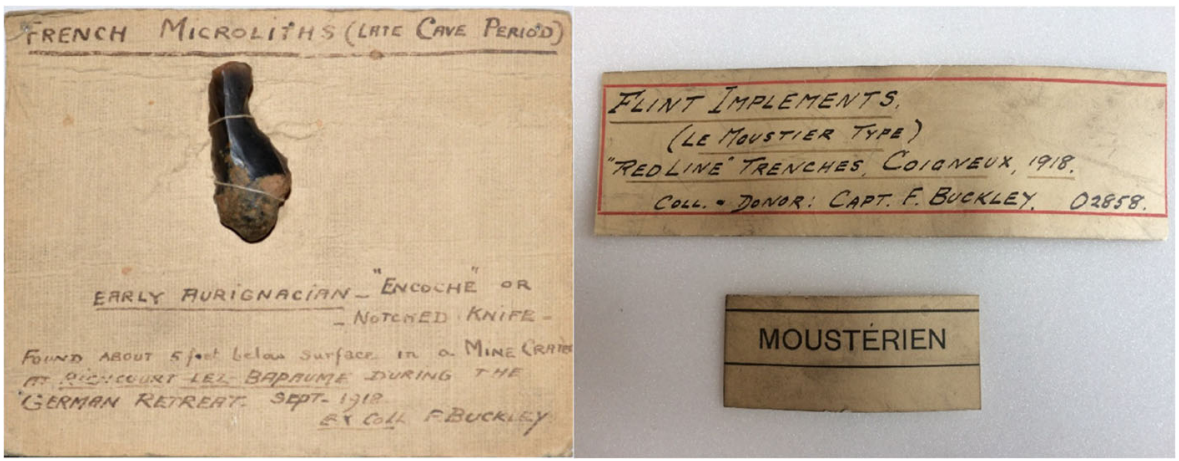

Fig. 3 Left: a lithic Buckley recovered on the Western Front, with original card detailing the findspot-a mine crater during the German retreat September 1918 (C Copyright Tolson Museum). It would now be defined as a notched flake, most likely Neolithic or later (Anderson-Whymark, pers. comm) Right: a deposition label for a "Red Line" hand-axe (C) Manchester Museum, The University of Manchester)

along with later polished-stone axe-heads and flakes. In one of the first publications of such wartime archaeology on the Western Front, in Proceedings of the Prehistoric Society of East Anglia for 1920-21, Buckley noted that, "For about 15 or 20 yards along the parapets there was a good sprinkling of implements, some recently broken and some whole ... [including] a hand axe ..., a typical Levallois flake and a number of scrapers" (Buckley 1920-21:4, Saunders 2007:4-5; Fig. 5).

In his fieldwork notebooks, intended for military observation, Buckley identified lithic findspots and the date of recovery using British Army map sheets and a grid system based on the Belgium National Grid. More painstakingly, he described the raw materials, degrees of patination, the parent deposits, and he produced stratigraphic section drawings of the trenches or shell holes from which artifacts were recovered. He identified bulbs of percussion and breaks on the artifacts, and in some cases he identified tool types and cultural groupings (such as "Aurignac"). Comparisons of his
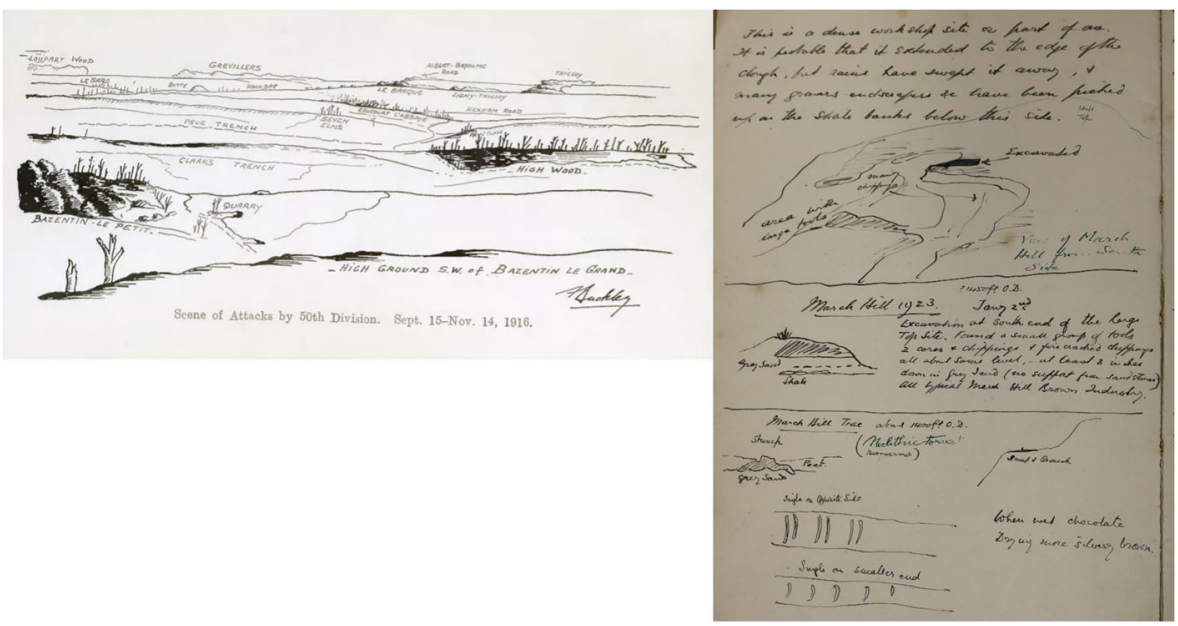

Fig. 4 Left: a facsimile of one of Buckley's 1918 intelligence work panoramas reproduced in his memoir. Right: his application of the technique for archaeological recording in the 1920s at on the key Mesolithic site, March Hill (Griffiths 2014) (@ Tolson Museum) 

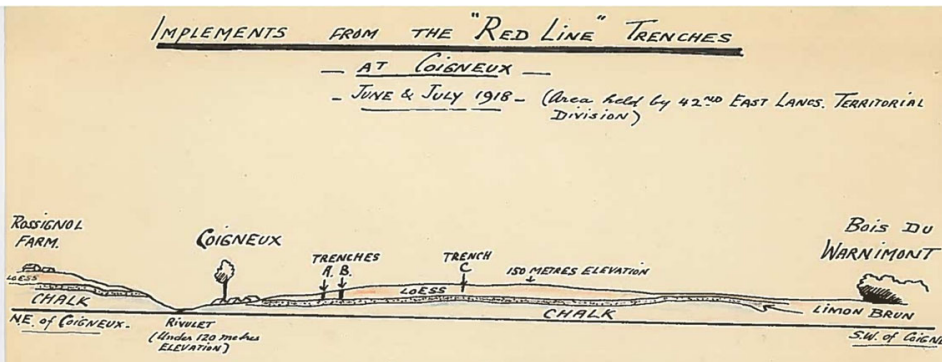

Section of Gisineux VasLey ac (net to reale)

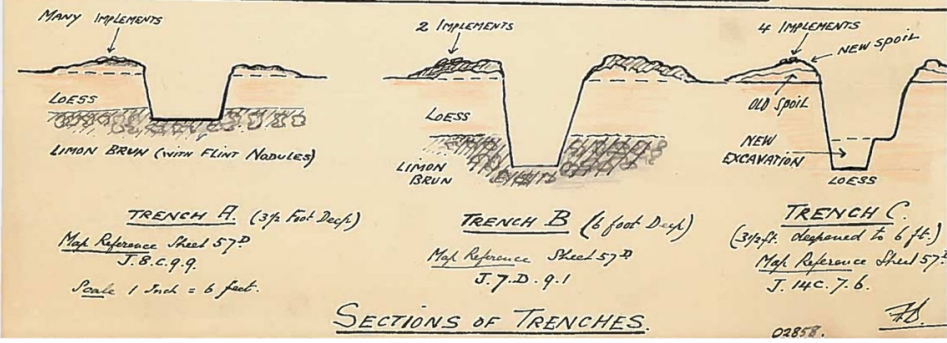

Fig. 5 The hand-tinted cross-sections Buckley produced from around Coigneux (` Manchester Museum, The University of Manchester)

original sketches show the debt that this early archaeological aesthetic owed to military fieldcraft and recording, as can be seen when Buckley's section drawings locating the "Red Line" finds from Coigneux are compared with drawing conventions from the British Infantry Officers' instruction manuals (Fig. 6).

Buckley paid special attention to the excavated ground at the suggestion of R. A. Smith of the British Museum (Keeper of Archaeology from 1927-38), with whom Buckley must have been in contact with during the war. Buckley may even have sent some of his finds to Smith for identification during the war; find 12 in his 1918 notebook is annotated "sent to BM 22/7/18," though it is unclear how this was achieved (F. Buckley).

Strikingly, Buckley referred to his time commanding the Divisional Observersfrom March 1918, through the Second Battle of Arras and the 1918 offensives - as "the most pleasant command that I held during the war" (Buckley 1920: 238). Indeed, the choice of "Adam" and "Eve" as names for two of the O.P.s suggests a very odd kind of personal Eden.

\section{After Conflict}

Buckley's experiences after the war are framed by the tragic impact it had on his immediate family. At the start, his brother Richard had probably committed suicide, and toward the end, on June 25, 1918, his sister, Florence - a Voluntary Aid Detachments (VAD) nurse - died in the Spanish Influenza epidemic. She is the only woman listed on the Alderman's Hill war memorial on Saddleworth Moor, where Buckley led an annual memorial service. 


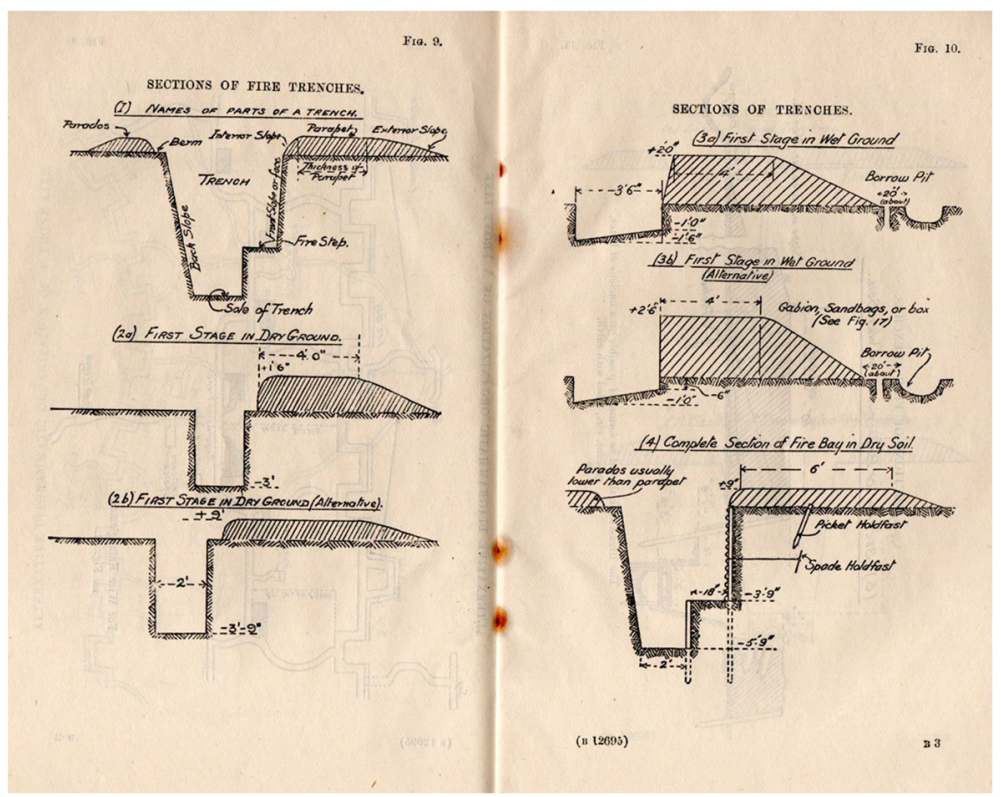

Fig. 6 An illustration from Notes on Trench Warfare for Infantry Officers: Revised Diagrams, December 1916 produced by His Majesty's Stationery Office General Staff, a technical pamphlet for the excavation of trenches. As a Pioneer, earthworks and digging-in were foundations of Buckley's military practice. The aesthetics military of trench illustration can be seen when comparing this image with Buckley's section drawing of his archaeological practice in the First World War, as shown in Fig. 3. (@ the Crown)

The war had a significant psychological effect on Buckley himself, and its impact was attested by his children. His daughter, Maude, said the war "changed him forever as a person" (Oldham Local Studies and Archives archive, MF-M34). More importantly for his archaeology, Buckley's second son, George (Fig. 7), stated that his father:

never practiced as a barrister after the War. He could not stand enclosedspaces - part of the effects of the war; being in cellars and doug-outs and having been under constant shellfire. He would have liked to $h$ ave gone on serving the Army.This is what drew him out to walk in the open spaces and to his work on flints (G. Buckley n.d.a, n.d.b, n.d.c).

Buckley's religious faith was seemingly not affected by his experiences; he served as a lay preacher during the Second World War. But, he does seem to have felt guilty about some aspects of his First World War action; in an obituary, his local priest wrote that "we said to him that we wished he had been ordained, [Buckley] replied that his conscience prevented him... in the last war I have shed blood and that is what hindered me" (John Gilks Archive, Saddleworth Museum and Art Gallery). Does this perhaps allude to the title of Buckley's war memoir, and the heavy artillery fire that he and his men called in on German soldiers as they watched from a distance? It was Buckley's job to watch Q6A, up close through a telescope, and perhaps the most important aspect 


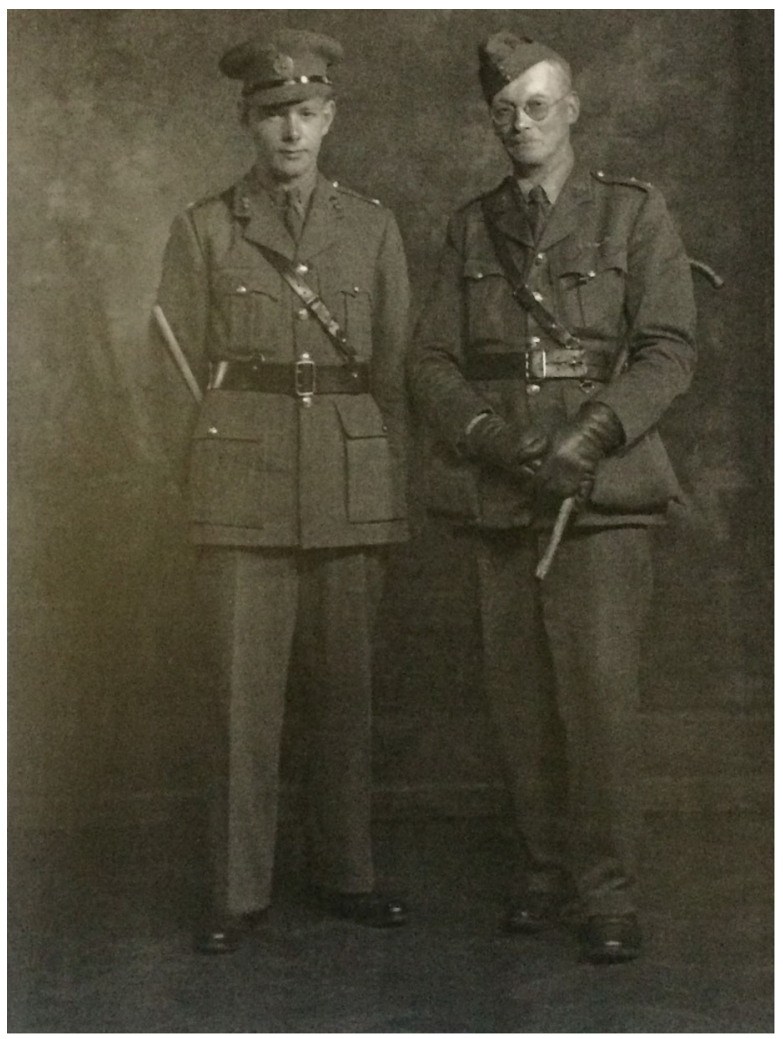

Fig. 7 Francis Buckley back in uniform in the Second World War, with his son George, about 1942. The chance to be of service again brought a halt to Francis' lithic work (@ Saddleworth Museum and Art Gallery)

of his experiences in the war, both in his military intelligence work and later as an archaeologist, was that he became an observer.

Buckley's own attitude to the First World War was unambiguous, the "tragedy of it all is written in one word. Waste - waste of lives, waste of effort, waste of ammunition" (Buckley 1920: 69). For archaeology, however, it was a different story.

Immediately after the war, Buckley produced a burst of publications and, following these, fieldwork. His publications again interweave conflict and archaeology, as two related forms of practice in terms of Buckley's wartime experiences. There was a surge of fieldwork from 1920 just after he completed the regimental history (Buckley) and his war memoir (Buckley 1920). Buckley published his 1918 "Red Line" finds in 1922, listing about 50 lithics, including the contexts of discovery (Buckley 1919a, 1919-22:4; see Fig. 5). In addition, up to 82 more lithics may be illustrated in his 1918 notebook (John Gilks Archive, Saddleworth Museum and Art Gallery) of which 39 have associated grid references. Given the lethal operating conditions, this was an extraordinary achievement.

Back in Yorkshire, Buckley spent much time "tramping" Saddleworth and Marsden moors, collecting and excavating lithic sites. Here, Buckley's unofficial research home, the Tolson Museum, Huddersfield, exemplifies most poignantly the importance of the Great War on all aspects of his post-war collecting practice. This museum was itself a war 
memorial, established by a 1919 bequest from Legh Tolson. The building and its parkland was formerly Tolson's private house, donated to the people of Huddersfield in memory of his two nephews, the brothers Robert Tolson and James Tolson, who died in the war. In this war memorial building, Francis Buckley collaborated in his archaeological research with the first curator, T. W. Woodhead, illustrating the complex link between conflict, loss, memory, and the civic preservation and presentation of the past (Fig. 8).

From the 1920 s to the 1940s, Buckley collected tens of thousands of artifacts, mainly near his Pennines home, but also in Northumberland where his wife Bebba's family lived (Brewis and Buckley 1928). His notebooks indicate that from one site, March Hill on Marsden Moor, over three years (1920-23) he recovered around 6,868 surface-finds, and excavated a further 1,159 lithics (Tolson Museum, AN 43.7.57). In his peacetime fieldwork, Buckley applied the skills he had learnt in his wartime fieldwork (see Fig. 3); he drew sections, recorded panoramas (see Fig. 6), located findspots on maps. The ascetic environment may have brought to mind the conditions of war.

Part of Buckley's importance is that his is one of the most significant collections of prehistoric lithic material produced by an individual in Britain; it is made significant by his application of wartime field-recording practices to contextualize his research. He drew his own finds, recorded elevation above sea level, and noted the field conditions. He was out on the moors in all weathers. On January 1, 1924, for example, his

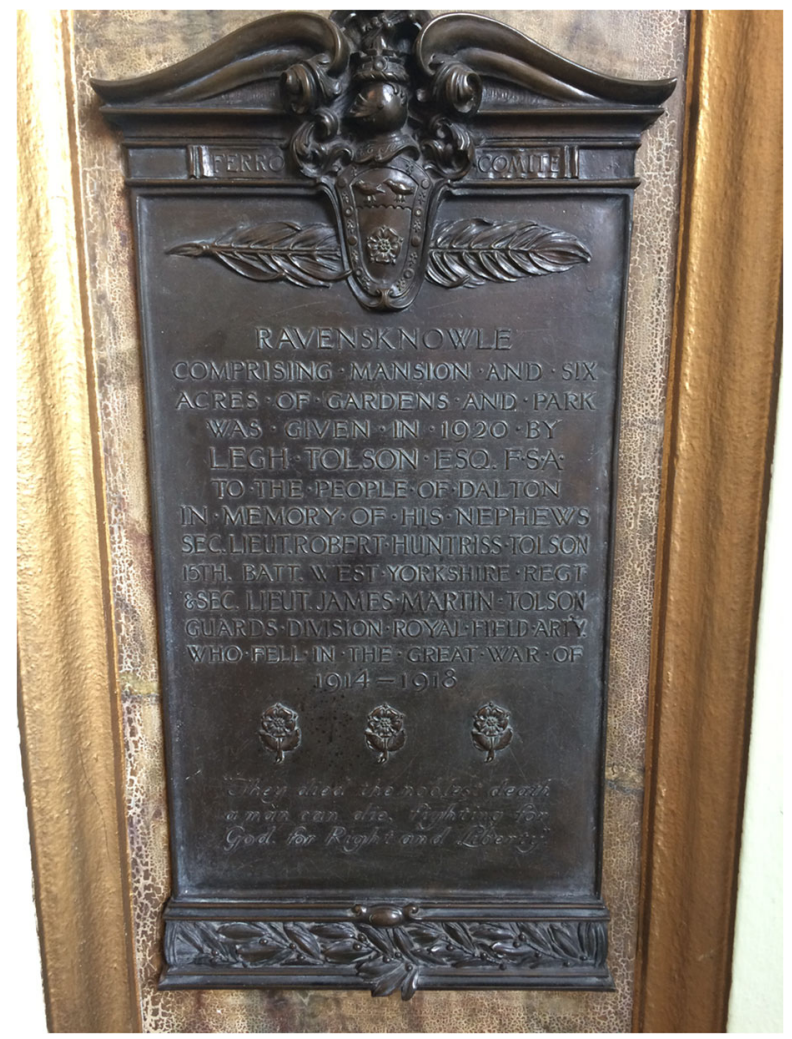

Fig. 8 The First World War memorial at the Tolson Museum (ㄷ Griffiths) 
notebook states he is at March Hill, in a northwest wind, with fog "after the frost." Throughout that month, he excavated and collected for 21 days in adverse weather conditions apparently on his own, though he often took his brother, children, or other friends (Tolson Museum, AC 43.12.57). He walked to his sites from the nearest station or wherever he could park his dog-cart, so his collecting always involved physical exertion even without excavation and difficult weather conditions.

Buckley's notebooks from the 1930s end in July 1939, from that time to 1942 he served in the West Yorkshire Regiment, Army Legal Division (Smith 2012:10). Buckley's archaeology was further entwined with conflict when he returned to collecting in 1944 after a Liverpool Museum request that he replace a previouslydonated collection which had been damaged during the Blitz (Tolson Museum, AN 43.12.57). There is then another lull until the Spring of 1948. Earlier that year his eldest son, John, had died. On April 2, Buckley was out collecting on Warcock Hill, south Pennines in a "boisterous, wet wind, but fine \& cold \& sunny \& Bebba's birthday." His last recorded "flinting" trip was on July 23, 1948, undertaking surface collection and excavation at a number of sites including on Warcock Hill (Tolson Museum, AC 43.12.57). Buckley's collecting practices seem to be in part in a response to personal trauma, a response he had first undertaken in the trenches of the First World War.

\section{Buckley's Contribution to Archaeology}

Grahame Clark (n.d.c) identified Buckley in 1992 as a "pioneer" who "set standards that in his own day were outstanding." Clark (n.d.c) also noted that his first encounter with Buckley in 1932 was "extremely valuable not only because of [Buckley's] admirably detailed work on the microlithic industries of the Pennines but also on account of the generous way in which he made his findings available to a young unknown student."

Buckley was elected a Fellow of the Society of Antiquaries in February 1927. The list of his sponsors is instructive; it includes a dazzling array of support. As well as his wartime archaeological contacts Spain and Smith, Society luminaries include Boyd Dawkins (a founding father of Paleolithic archaeology), Henry Balfour, (first curator of the Pitt Rivers Museum), E. T. Leeds (Assistant Curator at the Ashmolean Museum), and Miles Burkitt (first Lecturer in Prehistoric Archaeology at Cambridge University) who excavated with Abbé Breuil and Hugo Obermaier.

Buckley was clearly well-networked, and his sponsors demonstrate the context of his work in a place of transition and generational change, combining "the old guard" of wealthy but avocational Victorian researchers, and a new generation who were establishing archaeology and anthropology formally as an academic discipline in universities. Despite his connections, Buckley resigned from the Society in 1938 for unknown reasons. It is interesting, given the role of the First World War in the development of archaeology and the contribution of particular individuals, that Buckley appears never to have met O. G. S. Crawford (Hauser 2008). Crawford, a member of the British Third Army Topographical Section, was producing photographic panoramas of the Western Front, and collecting material culture (mainly flint implements) from the trenches (Hauser 2008:31-32), though less systematically than Buckley. He seems to have 
shared with Buckley a disregard for personal safety, as his bullet-smashed camera, illustrated in his autobiography, showed (Crawford 1955: plate 6).

Buckley had started his archaeological fieldwork in Britain by at least 1920, and began publishing his results in 1921, with more in 1924. Graham Clark was at this point a 25-year-old doctoral student at Cambridge, and it was his supervisor Miles Burkitt who introduced the two men. Buckley and Clark met in 1932 at Buckley's house near Saddleworth, where Buckley discussed his findings, took Clark onto the moors, introduced him to T. D. Woodhead (curator of the Tolson Museum) and, significantly, lent Clark his notebooks. These contained observations from 12 years of lithic collecting and classifying, and were invaluable records of Buckley's findings, because he had a policy of dispersing his collection to museums across England. A subsequent result is that his collection has never been analyzed or exhibited in toto, a significant loss for British Mesolithic studies.

Because of Buckley's generosity, Clark had access to records and analysis of what must have been one of the largest lithics assemblage recovered in Britain at that time. Buckley had used this mass of data to suggest that "narrow blade" Mesolithic lithics industries were characteristically later than "broad blade" Mesolithic industries (F. Buckley, G. Clark 1932: xx), and that these represented two distinct stone tool industries in the Pennines - a key to understanding the British Mesolithic.

Clark's resultant 1932 volume The Mesolithic Age in Britain defined the "conventional culture history approach" (Rowley-Conwy 1999: 508) that provided the first intellectual framework for European Mesolithic studies. While Westropp (1872) had introduced the concept of the "Mesolithic," it was not until Clark's work some 60 years later that the "Mesolithic" received its first detailed academic attention (Daniel 1981:103). In the 1932 volume and the 1936 volume, The Mesolithic Settlement of Northern Europe, Clark created Mesolithic archaeology as an academic field, with a "profound effect on the development of prehistory across Europe and beyond" (Barker 2014: 225). Clark's influence derived from the role that Cambridge had in developing international archaeological practice not only through his own publications, but through his "world-pervasive Cambridge school of thought" (Addyman 1995:13).

Despite Clark's extensive use of Buckley's material and records, the relationship between the two men may not always have been an easy one. In 1931, prior to publishing The Mesolithic Age in Britain, Clark returned Buckley's notebooks writing that these had been of "very great service to me" and that Buckley's work was "fundamental to the proper understanding of our mesolith [sic] period" (G. Clark n.d.-a). Using Buckley's research, Clark believed he had "worked out a satisfactory scheme for the country as a whole" (G. Clark n.d.-a). Rather belatedly perhaps, Clark asks "I hope you will not mind my using your drawings to make composite illustrations?" Clark then goes on to paraphrase the parts of Buckley's work from which he (Clark) draws his main conclusions, adding somewhat disingenuously "I think you will find that the importance of your work has been acknowledged \& emphasised [sic] (not that it required this for the inner circle!)" (G. Clark n.d.-a). By 1938, Buckley was withdrawing from academic circles, at least by resigning from the Society of Antiquaries. In contrast, by November 1939, Clark, had established himself as Honorary Editor of the now national Proceedings of the Prehistoric Society journal, and returned Buckley's photographs "with compliments," but no other comment (G. Clark n.d.-b). 
An intertextual analysis of Clark's The Mesolithic Age in Britain demonstrates the significance of Buckley's work, and tangentially the impact Buckley's First World War experiences had on the history of archaeological thought. In Clark's (1932: 218) seminal volume, Buckley is the single most cited individual in the index, with at least 10 references to his name. The "Pennine Industries" receive 17 citations (G. Clark 1932: 221), with a further 20 citations of the individual site names on which Buckley worked. This was the largest citation of any individual site or group of sites in Clark's text. In contrast, the influential "Belgian Industries" received 11 citations by Clark, the Abbé Breuil (perhaps the most pre-eminent early Holocene researcher in Europe at the time) receives only six references, Miles Burkitt a single citation, and the innovative Paleolithic archaeologist Dorothy Garrod only three (G. Clark 1932: 217-223). Buckley's notebooks or museum collections provide $10 \%$ of the finds illustrations (G. Clark 1932:ix-xi). There is a stark contrast here between the influence on Clark of established academic figures, and of an amateur war veteran on windswept Yorkshire moors; the contribution Buckley made to Clark's thinking and 1932 and 1936 monographs, as well as the subsequent history of Mesolithic studies, has been significantly underrecognized.

Buckley's innovations went beyond emphasizing the forms of different tool types as the basis for the subdivision of the British Mesolithic. From the 1920s onward, he also collected charred plant remains from his excavations, which in one of the first instances of its kind, were identified to species level by Woodhead at the Tolson Museum, and used for palaeoclimate reconstruction (e.g., F. Buckley). This emphasis on palaeoenvironmental work was hugely innovative at the time, coming some eight years before Godwin's first work on pollen analysis from the North Sea, and before Clark's Fenland Research Committee was formed (Coles 1997: 363-364). Given Buckley's influence on Clark's writings in other contexts, Buckley's work may have contributed to Clark's subsequent emphasis on palaeoenvironmental studies, and contributed to the development of the "ecological school" led by Clark in Cambridge from the 1930s onward. The material legacy of this work takes Buckley's impact on Mesolithic research into the present. It was the radiocarbon measurements by Switsur and Jacobi (1975) on charcoals Buckley collected that provided the first scientific chronologies of Mesolithic Britain, and have recently shown the first chronological overlap with Neolithic practices in Britain (Griffiths 2014).

\section{Conclusions: Buckley, War, and Archaeology}

Francis Buckley was a modern archaeologist, made so by his physical and psychological experiences on the Western Front during the First World War. The war exposed Buckley to landscapes old and dangerously new, to the archaeology that was literally thrown up from them, and the analytical skills to understand it. The Western Front was, after all, composed of two of the longest "archaeological" trenches in history (Saunders 2002:102).

Buckley's training as a Pioneer, Observer, and Intelligence Officer-in excavation, map reading, aerial photograph interpretation, recording sections and plans, and making panorama sketches - defined his subsequent archaeological practice. His wartime panoramas pinpointed enemy sites for artillery, and in peacetime located archaeological sites in the landscape. Buckley's battlefield "trampings," often under heavy enemy fire, were matched by his post-War fieldwork on the Yorkshire moors. The resonance 
between "battlefield" and "archaeological fieldwork" is underlined by Buckley's use of the same vocabulary to describe both practices. We can quite clearly see how the incidental, military aesthetic conventions demonstrated in the British Infantry training manuals directly influenced Buckley's wartime and post-war archaeological recording (see Figs. 4 and 5). Similar convergence of archaeological practices and methods developed in a different military context can be seen in the experience of Pitt Rivers (Evans 2014). For Buckley though, the psychological impact of war was as important in his subsequent work as his exposure to the modern methods of conflict. The privations of war were simulated in the conditions of his post-war fieldwork. In the midst of war, archaeological fieldwork provided a means of solace, in peacetime archaeological practice provided an escape from the trauma of war.

Buckley's financial independence allowed him to undertake research outside academia, to define himself as, and to remain, an outsider. As such, he appeared unmotivated to court either academic audience or career, or even to continue membership of the otherwise professionally useful Society of Antiquaries. Buckley's archaeological practice was personal, publishing what he wanted on his own terms-some early discoveries were reported in columns in local newspapers like The Oldham Chronicle and in privately published pamphlets rather than in academic journals. He was offered, but turned down, at least one Museum curatorship (Oldham Local Studies and Archives archive, MF-M34). In this, he differed from his career-oriented contemporaries, Crawford's "heroic band" of Clark, Christopher Hawkes, Stuart Piggott, Gordon Childe, and Mortimer Wheeler (Hauser 2009:72). Yet even here, the influence of global conflict is clear. The First World War not only created a new future, but helped create a new past, along with ways of investigating and understanding it.

Francis Buckley inhabited a landscape of transition in the history of archaeological thought and practice, his work contributed to the establishment of Mesolithic studies within British Prehistory between late nineteenth-century, high-Victorian antiquarians and the professional establishment of academic archaeology in the early twentieth century. Buckley's emphasis on recording, classification, and early use of scientific techniques placed him well ahead of his time, with all the characteristics of modern, scientific, positivist, archaeological practice. Buckley the man and the archaeologist was shaped by conflict, experiences of which combined to make him a key, if largely unheralded, figure in the making of Modern British archaeology.

Acknowledgments This work was made possible by access to various archives in the United Kingdom: at Oldham Local Studies library, Oldham Museum, the Tolson Museum, Manchester Museum, and Saddleworth Museum and Art Gallery, and in consultation with curators at Liverpool Museum and Touchstones Museum. Bryan Sich, Katina Bill, and Peter Fox are especially thanked. John Gilks did invaluable work curating much of Francis Buckley's archive and life history in his role as Curator of Archaeology at the Tolson Memorial Museum, Huddersfield 1967-91, and this paper is dedicated to him. Part of this research was undertaken while Griffiths was in receipt of a United Kingdom Arts and Humanities Research Council grant funding her PhD at Cardiff University.

Open Access This article is licensed under a Creative Commons Attribution 4.0 International License, which permits use, sharing, adaptation, distribution and reproduction in any medium or format, as long as you give appropriate credit to the original author(s) and the source, provide a link to the Creative Commons licence, and indicate if changes were made. The images or other third party material in this article are included in the article's Creative Commons licence, unless indicated otherwise in a credit line to the material. If material is not included in the article's Creative Commons licence and your intended use is not permitted by statutory 
regulation or exceeds the permitted use, you will need to obtain permission directly from the copyright holder. To view a copy of this licence, visit http://creativecommons.org/licenses/by/4.0/.

\section{References}

Addyman, P. (1995). Grahame Clark. Obituary. British Archaeology 8(8): 13.

Barker, G. (2014). Grahame Clark. 1907-95. In Fagan, B. (ed.), The Great Archaeologists. Thames and Hudson, London, pp. 224-228.

Biddle, S. (n.d.). Fieldwork in Egypt during World War 1. Different Perspectives: Archaeology and the Middle East in WWI. Petrie Museum, University College London, UK. https://historyofarchaeologyioa. weebly.com/different-perspectives-project. Accessed June 2020.

Brewis, P. and Buckley, F. (1928). Notes on prehistoric pottery and a bronze pin from Ross Links, Northumberland. Archaeologia Aeliana 4 (5):13-26.

Brown, M. (2009). "Slowly our ghosts drag home": human remains from the Heidenkopf, Serre, Somme, France. In Saunders, N. J. and Cornish, P. (eds.), Contested Objects: Material Memories of the Great War. Routledge, London, pp. 266-279.

Buckley, F. (ed.) (1919a). War History of the Seventh Northumberland Fusiliers in France and Flanders. Grierson, Newcastle.

Buckley, F. (1919-22). Finds of Flint Implements in The Red Line Trenches At Coigneux, 1918. Proceedings of the Prehistoric Society of East Anglia 3: 380-388.

Buckley, F. (1920). Q6A and Other Places. Recollections of 1916, 1917, 1918. Spottiswoode Ballantyne, London.

Buckley, F. (1924). A Microlithic Industry of the Pennine Chain: Related to the Tardenoise of Belgium. Privately printed pamphlet. Bodleian Library, University of Oxford.

Buckley, F. (n.d.a) Unpublished notebook with "1918” on flyleaf. John Gilks Archive, Saddleworth Museum and Art Gallery, Saddleworth, UK.

Buckley, F. (n.d.b). Unpublished correspondence dated "12 March 1924." Francis Buckley Archive, Tolson Museum, Huddersfield, UK.

Buckley, G. (n.d.c). Unpublished correspondence dated “18 May 1992.” John Gilks Archive, Saddleworth Museum and Art Gallery, Saddleworth, UK.

Clark, J. (1932). The Mesolithic Age in Britain. Cambridge University Press, Cambridge.

Clark, J. (1936). The Mesolithic Settlement of Northern Europe. Cambridge University Press, Cambridge.

Clark, R. (1960). Sir Mortimer Wheeler. Phoenix House, London.

Clark, J. (n.d.a). Unpublished correspondence dated "13 December 1931." Francis Buckley Archive, Tolson Museum, Huddersfield, UK.

Clark, J. (n.d.b). Unpublished correspondence dated "16 November 1939.” Francis Buckley Archive, Tolson Museum, Huddersfield, UK.

Clark, J. (n.d.c). Unpublished correspondence dated "10 June 1992.” John Gilks Archive, Saddleworth Museum and Art Gallery, Saddlewort, UK.

Coles, J. (1997). John Grahame Douglas Clark 1907-95. Proceedings of the British Academy 94: 357-387.

Cornish, P. (2009). "Just a boyish habit" ...? British and Commonwealth war trophies in the First World War. In Saunders, N. J. and Cornish, P. (eds.), Contested Objects: Material Memories of the Great War. Routledge, London, pp. 11-26.

Cowen, J. (1962). Lt-Col. G. R. B. Spain, C.M.G., F.S.A. Archaeologia Aeliana 40:283-287.

Crawford, O. (1955). Said and Done: The Autobiography of an Archaeologist. Weidenfeld and Nicolson, London.

Daniel, G. (1981). A Short History of Archaeology. Thames and Hudson, London.

Donaldson, J. and B. Asmussen. (2020) Collecting antiquities during wartime - the First World War Antiquities Project. https://blog.qm.qld.gov.au/2020/05/13/collecting-antiquities-during-wartime-thefirst-world-war-antiquities-project/. Accessed July, 2020.

ECA (n.d.) Egypt Conflict Archaeology: The Visual and Material Culture of Military Encounters with Egypt, 1914-1918 / 1939-1945. https://www.facebook.com/egyptconflictarchaeology/ Accessed July, 2020.

Evans, C. (2014). Soldiering archaeology: Pitt Rivers and militarism. Bulletin of the History of Archaeology 24 (4). https://doi.org/10.5334/bha.244

Gosden, C. (1999). Anthropology and Archaeology: A Changing Relationship. Routledge, London. 
Gough, P. (2009). "Calculating the Future": panoramic sketching, reconnaissance drawing and the material trace of war. In Saunders, N. J. and Cornish, P. (eds.), Contested Objects: Material Memories of the Great War. Routledge, London, pp. 237-250.

Griffiths, S. (2014). Points in time: the chronology of rod microliths. Oxford Journal of Archaeology 33: 221243.

Hauser, K. (2008). Bloody Old Britain. O. G. S. Crawford and the Archaeology of Modern Life. Granta, London.

Hauser, K. (2009). Bloody Old Britain. O.G.S. Crawford and the Archaeology of Modern Life. Granta, London.

His Majesty's Stationery Office General Staff. (1916). Notes on Trench Warfare for Infantry Officers: Revised Diagrams, December 1916. His Majesty's Stationery Office, London.

Mackie, C. J. (2010). Archaeology at Gallipoli in 1915. In Tamis, P., Mackie, C. J., and Byrne, S. G. (eds.), Philathenaios. Helleniki Epigrafiki Hetaireia, Athens, pp. 209-221.

Piggott, S. (1977). Robert Eric Mortimer Wheeler 10 September 1890-22 July 1976. Elected F.R.S. 1968. Biographical Memoirs of Fellows of the Royal Society 23:623-642.

Rowley-Conwy, P. (1999). Sir Graham Clark 1907-1995. In Murray, T. (ed.) Encyclopedia of Archaeology: The Great Archaeologists. ABC-CLIO, Santa Barbara, pp. 507-529.

Saunders, N. J. (2002). Excavating memories: archaeology and the Great War, 1914-2001. Antiquity 76 (1): 101-108.

Saunders, N. J. (2003a). Trench Art: Materialities and Memories of War. Berg, Oxford.

Saunders, N. J. (2003b). Crucifix, calvary and cross: materiality and spirituality in Great War landscapes. World Archaeology 35 (1): 7-21

Saunders, N. J. (2004). Material culture and conflict: the Great War, 1914-2003. In Saunders, N. J. (ed.), Matters of Conflict: Material Culture, Memory and the First World War. Routledge, London, pp. 5-25.

Saunders, N. J. (2010). Killing Time: Archaeology and the First World War. 2nd ed. Sutton, Stroud.

Saunders, N. J. (ed.) (2012). Beyond the Dead Horizon: Studies in Modern Conflict Archaeology. Oxbow, Oxford.

Shapland, A. and Stefani, E. (eds.) (2017). Archaeology Behind the Battle Lines: The Macedonian Campaign (1915-19) and its Legacy. Routledge, London.

Smith, G. (2012). Francis Buckley. Saddleworth History Society Bulletin 42: 1-11.

Switsur, V. and Jacobi, R. (1975). Radiocarbon dates for the Pennine Mesolithic. Nature 256: 32-4.

VAL (n.d.). Views of an Antique Land. https://www.cardiff.ac.uk/research/impact-and-innovation/researchimpact/views-of-an-antique-land. Accessed July, 2020.

Westropp, H. (1872). Pre-Historic Phases; or, Introductory Essays on Pre-Historic Archoeology. Bell and Daldy, London.

Wheeler, M. (1955). Still Digging. Michael Joseph, London.

Publisher's Note Springer Nature remains neutral with regard to jurisdictional claims in published maps and institutional affiliations. 